Revista Iberoamericana, Vol. LXXV, Núm. 226, Enero-Marzo 2009, 17-19

\title{
PIÑERA POLIÉDRICO
}

\author{
POR \\ JESÚs JAMBRINA \\ Viterbo University
}

A pesar de lo frecuentemente que se menciona el nombre del escritor cubano Virgilio Piñera(1912-1979) en las publicaciones literarias y académicas del continente, puede decirse que el autor es todavía poco conocido. Estudiado principalmente como dramaturgo y narrador -con la excepción de La isla en peso (1944)- su obra poética ha recibido menos atención. Más allá de los acercamientos críticos de Cintio Vitier (Lo cubano en la poesía, 1957), Enrique Saínz (La poesía de Virgilio Piñera, 2001), y Alberto Abreu (Virgilio Piñera, un hombre, una isla, 2000), el trabajo poético piñeriano no ha sido objeto de una crítica sistemática. ${ }^{1}$ Mucho menos su labor crítica y periodística que se extiende a la Argentina entre 1946 y 1958. Luego el objetivo principal de este dossier es explorar algunas áreas del trabajo de Virgilio Piñera que por una u otra razón no han tenido mayor espacio en las reflexiones sobre su obra.

De su poesía interesa aquí la escrita después de 1959, así como sus intentos de teorizar sobre este género literario a lo largo de su vida. En cuanto al periodismo, aquel que practicó en los primeros dos años de la revolución cubana, y de su estancia en Buenos Aires, la relación amistosa e intelectual con Jorge Luis Borges. Por último, se analiza la lectura crítica que Cintio Vitier hizo de Piñera en 1945, la cual ha servido de base conceptual para la valoración del autor en los últimos sesenta años.

En el ensayo de Pilar Cabrera Fonte se aborda el trabajo piñeriano desde los estudios queer, una vertiente que ha sido poco utilizada con respecto al autor si pensamos que su vida y obra estuvo marcada por la irreverencia sexual y la crítica de instituciones sociales como la familia, la cultura y la religión. Cabrera Fonte piensa la mutilación como metáfora del disciplinamiento del sujeto en el

\footnotetext{
${ }^{1}$ En los tres casos, los críticos enfatizan la poesía que Virgilio Piñera escribió antes de 1959, sumando, cuando más, la escrita a comienzos de los sesenta. Pero en ningún caso tienen en cuenta los giros temáticos y estilísticos que el autor experimentó en los últimos diez años de su creación, los cuales invitan a reconsiderar los fundamentos estéticos piñerianos.
} 
espacio moderno. Entra así en una dimensión de la poesía del autor en la cual el trabajo de éste escapa a las reducciones nacionalistas a las que más de una vez se ha visto confinado el estudio de su obra, entrando a un circuito más amplio de consideraciones. Rita Martín, por su parte, rastrea el contenido epistemológico de algunos de los ensayos críticos de Piñera sobre poesía. Si puede hablarse de un metatexto narrativo en Piñera, así como de un metateatro, en este caso Martín demuestra que también sobre poesía el autor elaboró una narrativa crítica simultánea al trabajo poético mismo.

En un segundo momento de este dossier se encontrarán dos estudios que tratan sobre facetas, si no desconocidas, sí poco mencionadas y abordadas críticamente: su estancia en Buenos Aires y en particular su amistad con Jorge Luis Borges, y lo que pudiera llamarse el Piñera político, si aceptamos el término político como sinónimo de militancia, en este caso revolucionaria. Acerca del primer tema, Alfredo Alonso lee aquellos momentos en que Borges y Piñera dialogan, ya sea mediante gestos civiles -después de la publicación de los criterios piñerianos sobre la literatura argentina, Borges invita al cubano a publicar un cuento en Anales de Buenos Aireso juegos literarios, como las alusiones de Piñera a símbolos y metáforas aparecidos en los cuentos de Borges. La publicación reciente de las partes del diario de Adolfo Bioy Casares relativas a sus conversaciones con el escritor argentino confirma que Piñera no pasó desapercibido para Borges desde el punto de vista literario y que supo deslindar entre desacuerdos estéticos y mérito literario.

Por su parte, el texto de Thomas F. Anderson se centra en los artículos y editoriales que el escritor publicó en el periódico Revolución y su suplemento cultural Lunes entre 1959 y 1961, fecha de cierre de esta conocida publicación de vanguardia. En esos escritos se demuestra que la filiación provocadora del autor incluye abiertamente lo político, exorcizando de esta forma los mitos de un Piñera alejado de los temas complicados de su tiempo. Anderson devela una zona de la escritura piñeriana que estaría llamada a desestabilizar el pánico ideológico que despertó en su momento. Como sabemos, después de un breve auge editorial entre 1959 y 1961, la figura y la obra de Piñera comenzaron a ser eliminadas del escenario cultural hasta ser completamente excluidas durante los últimos diez años de su vida. La pregunta que surge es: ¿por qué si Piñera apoyó la revolución, sin embargo, fue tan tempranamente censurado?

Finalmente, el texto del editor de este dossier regresa a lo que puede considerarse el punto cero de la crítica sobre Piñera: la reseña literaria que Cintio Vitier escribiera sobre Poesía y prosa (1944), aparecida en la revista Orígenes en 1945. Fue esta nota la que estableció la idea de un Piñera deudor de la nada y el vacío, categorías éticas y filosóficas en las que, desde entonces, se han basado los estudios críticos sobre el autor. En este último análisis se compara la lectura de Vitier con las tensiones 
poéticas del libro reseñado, así como con las referencias epistemológicas del propio Piñera a la(s) nada(s) y el vacío expuestas en varios ensayos literarios. Subrayando estas particularidades del contexto histórico se propone la reconstrucción de los estudios piñerianos usando evidencias interpretativas y sugiriendo un tratamiento democrático de las mismas. 
